\title{
STRANDED AND EQUILIBRATED ASSEMBLAGES OF LATE FELDSPARS IN TWO GRANITIC PEGMATITES IN THE PAMPEAN RANGES, ARGENTINA
}

\author{
PETR ČERNÝ§ \\ Department of Geological Sciences, University of Manitoba, Winnipeg, Manitoba R3T 2N2, Canada \\ Miguel A. GALLISKI \\ Laboratorio de Mineralogía y Geoquímica, IANIGLA - CRICYT - CONICET, 5500 Mendoza, Argentina \\ JuLIo C. OYARZÁBAL \\ Cátedra de Mineralogía, Universidad Nacional de San Luis, 5700 San Luis, Argentina \\ David K. TEERTSTRA, Ron CHAPMAN, Lyndsey MacBRIDE and Karen FERREIRA \\ Department of Geological Sciences, University of Manitoba, Winnipeg, Manitoba R3T 2N2, Canada
}

\begin{abstract}
Late primary K-feldspar in two granitic pegmatites from the Pampean pegmatite province in Argentina shows similar patterns of growth and exsolution, but different structural states and mineral associations. (i) In El Criollo, a beryl - columbite - phosphate pegmatite in the Punilla pegmatite field, a single miarolitic cavity in the blocky zone is lined with pale rusty crystals of veinperthitic K-feldspar and quartz. The Kfs host, $\mathrm{Or}_{89.7} \mathrm{Ab}_{7.8} \operatorname{Rbf}_{0.3} \operatorname{LEf}(?)_{1.1}\left(\square \mathrm{Si}_{4} \mathrm{O}_{8}\right)_{1.2}(\sim 88$ vol.\%), corresponds to optically and XRD-monoclinic, but highly $(\mathrm{Al}, \mathrm{Si})$-ordered orthoclase $\left(2 \mathrm{t}_{1}=0.82\right)$, with only a slight incipient conversion to intermediate gridtwinned microcline along contacts with exsolved low albite, $\mathrm{Ab}_{98.1} \mathrm{An}_{1.2} \mathrm{Or}_{0.9}(\sim 12 \mathrm{vol} . \%)$. The homogeneous precursor of the perthite contained $\sim 22$ mole $\% \mathrm{Ab}_{\mathrm{ss}}$. The perthitic orthoclase is overgrown, mainly on the $\{010\}$ faces, by nonperthitic, gemmy, pale grey to beige orthoclase, $\mathrm{Or}_{91.6} \mathrm{Ab}_{6.1} \mathrm{Rbf}_{0.5} \mathrm{Cn}_{0.2} \mathrm{Srf}_{0.1} \mathrm{LEf}(\text { ? })_{0.2}\left(\square \mathrm{Si}_{4} \mathrm{O}_{8}\right)_{1.5}$, with $2 \mathrm{t}_{1}$ equal to 0.84. Small tabular crystals of white low albite, $\mathrm{Ab}_{99.5} \mathrm{Or}_{0.7}$, elongate parallel to $c$, are situated on the $\{110\}$ faces of the orthoclase in epitactic orientation. (ii) In San Luis II, a spodumene pegmatite in El Totoral pegmatite field, crystals of coarsely perthitic K-feldspar and quartz line cavities in the core-margin zone. The mottled-grey euhedral K-feldspar, Or ${ }_{92.3} \mathrm{Ab}_{4.1} \operatorname{Rbf}_{1.1} \operatorname{Csf}_{0.1} \mathrm{Cn}_{0.1} \operatorname{Srf}_{0.1} \operatorname{LEf}_{(?)_{1.5}}\left(\square \mathrm{Si}_{4} \mathrm{O}_{8}\right)_{0.8}$ ( $\sim 92 \mathrm{vol} . \%)$, locally altered to muscovite and clay minerals, is very close to end-member low microcline with vein-shaped exsolution lamellae of low albite, $\mathrm{Ab}_{99.1} \mathrm{An}_{0.1} \mathrm{Or}_{0.4} \mathrm{Cn}_{0.1} \mathrm{Srf}_{0.1}(\sim 8 \mathrm{vol} . \%)$. The homogeneous precursor of the perthite contained $\sim 13$ mole $\% \mathrm{Ab}_{\mathrm{ss}}$. All faces of the perthite crystals have an even overgrowth of pale grey, nonperthitic low microcline, $\mathrm{Or}_{92.8} \mathrm{Ab}_{4.8}$ $\operatorname{Rbf}_{0.2} \operatorname{Srf}_{0.1} \operatorname{LEf}(?)_{1.8}\left(\square \mathrm{Si}_{4} \mathrm{O}_{8}\right)_{0.3}$. The cavity space among the crystals of the K-feldspar and primary quartz is largely filled by microcrystalline secondary quartz, "chalcedony", opal and goethite. Different subsolidus histories of the two host vugs explain the conspicuous contrast between the structural states of their cavity-lining K-feldspar. In El Criollo pegmatite, the cavity probably quickly lost residual aqueous fluid, as the orthoclase of both the primary perthitic crystals and particularly of the gemmy overgrowth show only stranded, coherent domain-scale order and twinning, and very limited alteration. In the San Luis II pegmatite, the cavity-lining K-feldspar shows considerable alteration and overgrowth by low-temperature phases, indicative of substantial hydrothermal activity, which promoted ( $\mathrm{Al}, \mathrm{Si})$-ordering to give tartan-twinned low microcline in both the primary perthitic crystals and the nonperthitic overgrowths.
\end{abstract}

Keywords: K-feldspar, granitic pegmatite, order-disorder, hydrothermal overprint, Argentina.

\section{SOMMAIRE}

Le feldspath potassique primaire qui s'est formé tardivement dans deux pegmatites granitiques de la province pegmatitique de Pampea, en Argentine, montre des points communs en termes de croissance et d'exsolution, mais des différences marquées en termes du degré d'ordre et d'associations minérales. (i) A El Criollo, une pegmatite à béryl - columbite - phosphate du champ pegmatitique de Punilla, une seule cavité miarolitique de la zone à cristaux polyédriques est tapissée de cristaux pâles de couleur rouille de feldspath potassique, perthitique à veines, avec quartz. L'hôte dans cette perthite, $\mathrm{Or}_{89.7} \mathrm{Ab}_{7.8} \mathrm{Rbf}_{0.3} \mathrm{LEf}(?)_{1.1}\left(\square \mathrm{Si}_{4} \mathrm{O}_{8}\right)_{1.2}$

§E-mail address: p_cerny@umanitoba.ca 
( $\sim 88 \%$ en volume), correspond optiquement et en diffraction $\mathrm{X}$ à une phase monoclinique (orthose) fortement ordonnée, avec $2 \mathrm{t}_{1}$ $=0.82$, et un début de conversion à la microcline intermédiaire avec maclage quadrillé le long des contacts avec l'albite ordonnée exsolvée, $\mathrm{Ab}_{98.1} \mathrm{An}_{1.2} \mathrm{Or}_{0.9}$ ( 12\% en volume). Le précurseur homogène de la perthite contenait $\sim 22 \% \mathrm{Ab}_{\mathrm{ss}}$ (base molaire). L'orthose perthitique est recouverte, surtout sur les faces $\{010\}$, d'une surcroissance d'orthose non perthitique, gemme, gris pâle à beige, $\mathrm{Or}_{91.6} \mathrm{Ab}_{6.1} \mathrm{Rbf}_{0.5} \mathrm{Cn}_{0.2} \operatorname{Srf}_{0.1} \operatorname{LEf}(?)_{0.2}\left(\square \mathrm{Si}_{4} \mathrm{O}_{8}\right)_{1.5}$, avec $2 \mathrm{t}_{1}$ egal à 0.84 . De petits cristaux tabulaires blancs d'albite ordonnée, $\mathrm{Ab}_{99.5} \mathrm{Or}_{0.7}$, allongés parallèles à $c$, recouvrent les faces $\{110\}$ de l'orthose, en relation épitactique. (ii) A San Luis II, une pegmatite à spodumène du champ de El Totoral, des cristaux grossiers et perthitiques de feldspath potassique et de quartz tapissent les cavités de la zone externe du coeur du massif. Les cristaux idiomorphes de feldspath potassique sont gris nuagé, $\mathrm{Or}_{92.3} \mathrm{Ab}_{4.1} \mathrm{Rbf}_{1.1} \mathrm{Csf}_{0.1} \mathrm{Cn}_{0.1} \mathrm{Srf}_{0.1} \operatorname{LEf}(?)_{1.5}\left(\square \mathrm{Si}_{4} \mathrm{O}_{8}\right)_{0.8}$ ( 92\% en volume), localement transformés en muscovite et en argiles; ils sont très près du pôle microcline ordonné, avec des lamelles exsolvées en veines d'albite ordonnée, $\mathrm{Ab}_{99.1} \mathrm{An}_{0.1} \mathrm{Or}_{0.4} \mathrm{Cn}_{0.1}$ $\mathrm{Srf}_{0.1}\left(\sim 8 \%\right.$ en volume). Le précurseur homogène de la perthite contenait $\sim 13 \%$ d'albite $\mathrm{Ab}_{\mathrm{ss}}$ (base molaire). Toutes les faces des cristaux de perthite sont recouvertes d'une surcroissance uniforme gris pâle de microline ordonné non perthitique, $\mathrm{Or}_{92.8} \mathrm{Ab}_{4.8}$ $\mathrm{Rbf}_{0.2} \operatorname{Srf}_{0.1} \operatorname{LEf}(?)_{1.8}\left(\square \mathrm{Si}_{4} \mathrm{O}_{8}\right)_{0.3}$. Les espaces entre les cristaux de feldspath potassique et de quartz sont surtout remplis de quartz microcristallin secondaire, "calcédoine", opale et goethite. Des différences dans l'évolution subsolidus des deux cavités hôtes expliquent le contraste frappant en termes du degré d'ordre du feldspath potassique sur les parois. Dans la pegmatite de El Criollo, la cavité a probablement perdu la phase fluide résiduelle rapidement; l'orthose des cristaux primaires devenus perthitiques et de la surcroissance gemme ne contient que des domaines ordonnés cohérents et maclés, conservés de façon métastable, et très peu d'altération. Dans la pegmatite de San Luis II, les cristaux de feldspath potassique le long des parois montrent des signes importants d'altération et de surcroissances de phases de basse température, indications d'une activité hydrothermale substantielle, qui a favorisé la mise en ordre $(\mathrm{Al}, \mathrm{Si})$ du feldpath pour mener à la forme à maclage quadrillé du microcline ordonné, aussi bien dans les cristaux perthitiques que dans les surcroissances non perthitiques.

(Traduit par la Rédaction)

Mots-clés: feldspath potassique, pegmatite granitique, ordre-désordre, modifications hydrothermales, Argentine.

\section{INTRODUCTION}

Along with quartz, feldspars are the most abundant components of granitic pegmatites, but our understanding of their crystal chemistry, crystallization history, geochemical evolution and order-disorder behavior remains in many respects sketchy. In general, systematic studies of rock-forming feldspars across individual pegmatite bodies are scarce, and much remains to be done to fully utilize the wealth of petrological information stored in these minerals (e.g., Cerný 1994, Blasi \& De Pol Blasi 2000). The late generations of subsolidus feldspars have attracted attention because of their extreme diversity in chemical composition, structural state and growth history (e.g., Foord \& Martin 1979, Černý \& Chapman 1984, 1986, Martin \& Falster 1986, Ferguson et al. 1991, Teertstra 1997, Teertstra et al. 1998a, 1999). However, the genetic and petrological development has only rarely been documented in conjunction with physical and compositional characteristics.

Here we examine and compare the composition, structural aspects, primary petrology and low-temperature modifications of two suites of late feldspars in two granitic pegmatites from the Pampean Ranges of Argentina, El Criollo and San Luis II. We document here two contrasting examples of the significance of the postcrystallization environment for shaping the final state of cavity-grown feldspars. The data and interpretations are all the more significant because they come from a pegmatite province that is virtually unknown in the literature as far as feldspars are concerned.

\section{EXPERIMENTAL}

The wavelength-dispersion method was used on a CAMECA SX-50 electron microprobe operating at 15 $\mathrm{kV}$ and $20 \mathrm{nA}$, with a beam diameter of $5 \mu \mathrm{m}$. Under these conditions, gain or loss of alkalis from the EMPAanalyzed volume is negligible. Standards were characterized using the procedure of Teertstra et al. (1998a, b), and data were reduced using the $P A P$ procedure of Pouchou \& Pichoir (1984, 1985). We used the following standards for feldspars and muscovite: Eifel sanidine $(\mathrm{K} K \alpha, \mathrm{A} 1 K \alpha, \mathrm{Si} K \alpha), \mathrm{VP}_{2} \mathrm{O}_{7}(\mathrm{P} K \alpha)$, albite $(\mathrm{Na} K \alpha)$, $\mathrm{Rb}_{2} \mathrm{ZnSi}_{5} \mathrm{O}_{12}$ glass $(\mathrm{Rb} L \alpha)$, forsterite $(\mathrm{Mg} K \alpha)$, pollucite $(\mathrm{Cs} L \alpha)$, anorthite $(\mathrm{Ca} K \alpha), \mathrm{SrTiO}_{3}(\mathrm{Sr} L \alpha, \mathrm{Ti} K \alpha)$, barite $(\mathrm{Ba} L \beta)$, fayalite $(\mathrm{Fe} K \alpha)$, PbTe $(\mathrm{Pb} M \alpha)$. Peak-counting times (and detection limits) were $20 \mathrm{~s}$ for $\mathrm{K}, \mathrm{Al}, \mathrm{Si}$ and $\mathrm{Ca}(0.07,0.06,0.09$ and $0.05 \mathrm{wt} \%$, respectively), $40 \mathrm{~s}$ for $\mathrm{Na}, \mathrm{Rb}$ and $\mathrm{Pb}(0.03,0.01$ and $0.04 \mathrm{wt} \%$, respectively), $100 \mathrm{~s}$ for $\mathrm{Cs}, \mathrm{Mg}, \mathrm{Sr}, \mathrm{Ba}, \mathrm{Fe}$ and $\mathrm{P}(0.01,0.006$, $0.02,0.04,0.01$ and $0.01 \mathrm{wt} . \%$, respectively), and $120 \mathrm{~s}$ for $\mathrm{Ti}(0.01 \mathrm{wt} . \%)$. The counting times and detection limits were reversed for $\mathrm{Na}$ and $\mathrm{K}$ in albite. The contents of $\mathrm{Pb}, \mathrm{Fe}, \mathrm{Mg}$ and $\mathrm{Ti}$ were found to be below the detection limits in all samples, and qualitative checks for $\mathrm{Ga}, \mathrm{Mn}$ and $\mathrm{F}$ gave null results.

The Eifel sanidine standard is of critical importance here, as it must give accurate contents of elements in other standards (within $\sim 2 \%$ error) and unknown feldspars (approaching 1\% error). The composition of our Eifel standard as reported by Teertstra et al. (1998a, b) was based on a correlation with compositions of hundreds of feldspar samples, whereas by now we have accumulated a few thousand compositions. This ex- 
tended database indicates a slight overestimate of $\mathrm{K} / \mathrm{Na}$ in the 1998 formula; our current best fit of the University of Manitoba Eifel standard composition is $\mathrm{K}_{0.708}$ $\mathrm{Na}_{0.265} \mathrm{Ba}_{0.020} \mathrm{Sr}_{0.004}\left(\mathrm{Al}_{1.015} \mathrm{Fe}_{0.006}\right) \mathrm{Si}_{2.979} \mathrm{O}_{8}$.

Feldspar formulas were calculated on the basis of 8 atoms of oxygen per formula unit (apfu). Monovalent and divalent cations were assigned to the $M$ site, and higher-valence cations, to the $T$-site of the general formula $M T_{4} \mathrm{O}_{8}$. The following quantities were used to characterize crystal chemistry of the feldspars: $\boldsymbol{M}^{\mathbf{1 +}}$ (sum of EMPA-established monovalent cations), $\boldsymbol{M}^{\mathbf{2}}$ (sum of EMPA-established divalent cations), $\boldsymbol{\Sigma} \boldsymbol{M}\left(M^{1+}+M^{2+}\right)$, $\boldsymbol{M}^{+}$(total charge on EMPA-determined cations), $\boldsymbol{T O}_{2}^{-}$ $\left(\mathrm{Al}+\mathrm{Fe}^{3+}-\mathrm{P}=\right.$ total charge on tetrahedral framework $)$, $\mathbf{S i}+\mathbf{2 P}=\mathrm{Si}+\mathrm{P}+$ Al-equivalent of $\mathrm{P}$ (equivalent of $\mathrm{Si}$ in P-free feldspar, according to berlinite substitution verified in plots of $\mathrm{Al}$ versus $\mathrm{P}$ and $\mathrm{Si}$ versus $\mathrm{P}), \Sigma \boldsymbol{T}$ (sum of $T$ cations), $\mathbf{L E f}(?)^{+}=\mathrm{TO}_{2}{ }^{-}-M^{+}$(total charge on light-element cations not determinable by EMPA: $\mathrm{Li}^{+}, \mathrm{H}^{+}, \mathrm{NH}_{4}^{+}$, equal to the number of monovalent cations), $\square \boldsymbol{T}=\mathrm{Si}+2 \mathrm{P}-3$ (vacancy at the $M$ site equal to "excess" $\mathrm{Si}$ ); $\square \boldsymbol{M}=1-[\Sigma M+\mathrm{LE}($ ?) $]$ (vacancy at the $M$ site based on the sum of analyzed and calculated $M$ cations), $\square \mathbf{S i}_{\mathbf{4}} \mathbf{O}_{\mathbf{8}}$ ["excess" Si via the substitution $\square \mathrm{Si}$ $\left.(\mathrm{K}, \mathrm{Na})_{-1} \mathrm{Al}_{-1}\right]$.

Three explanatory comments are required: (i) The two expressions of vacancy at $M$ are analytically independent of each other, and cannot be expected to match perfectly; the agreement of the values is good, and adequate to estimated analytical errors. (ii) The above quantities were not calculated for albite, as they are negligible, or zero. Therefore, they are strongly overprinted and rendered meaningless by analytical errors on EMPA-determined components. (iii) End-member components were calculated from $M$-site populations including vacancy (apfu) multiplied by 100 . Thus, the contents of the end-member components are quantified as measured on $M$ cations and not idealized by normalization, and consequently may not sum to exactly 100 mole $\%$.

$\mathrm{X}$-ray powder-diffraction data were collected from 19 to $51^{\circ}$ on a Philips PW 1729 diffractometer operating at $40 \mathrm{kV}$ and $40 \mathrm{~mA}$, with $\mathrm{Cu} K \alpha_{1}$ radiation $(\lambda$ $1.54056 \AA$ ), a $0.02^{\circ} 2 \theta$ step width, and a 4 s count time. Synthetic $\mathrm{BaF}_{2}$, NBS batch 00-02, with a value of $a$ of $6.1997 \AA$, was used as an internal standard. A modified version of the Appleman \& Evans (1973) program was used for least-squares refinement of the unit-cell dimensions. The procedures of Wright \& Stewart (1968) and Borg \& Smith (1969) were used to identify and select diffraction maxima for cell refinements. Aluminum contents of tetrahedral sites were calculated using equations 10a, 10b and 11 of Kroll \& Ribbe (1983, Figs. 4a, b) [cf. Smith \& Brown (1988), Figs. 7.9 and 7.10], to facilitate comparison with data from the pre-1987 literature, and are used in the text. However, values based on the Kroll \& Ribbe (1987, equations 5, 6 and 12) update, and on the classic $\Delta$ method as formulated by Blasi \& De Pol Blasi (1994), also are calculated for comparison.

\section{The El Criollo Granitic Pegmatites}

\section{The pegmatites}

The El Criollo granitic pegmatites belong to the Cerro Blanco pegmatite group, located west of the town of Tanti, at about $64^{\circ} 39^{\prime} \mathrm{W}, 31^{\circ} 21^{\prime} 50^{\prime \prime} \mathrm{S}$, in the Eastern Pampean Ranges of Córdoba Province (Fig. 1). The Cerro Blanco group belongs to the Punilla pegmatite field, which is comprised dominantly of pegmatites of the beryl - columbite - phosphate subtype emplaced into, or very close to, the post-tectonic Achala batholith, described by Morteani et al. (1995). The El Criollo pegmatites were dated by the $\mathrm{K}-\mathrm{Ar}$ method at $350 \pm 30$ Ma (Linares \& Latorre 1969).

The El Criollo pegmatites were mapped and described by Gallagher \& Jutorán (1971). The pegmatite occurrence consists of three very closely spaced bodies, the main being cylinder-like, $150 \mathrm{~m}$ long and up to 60 $\mathrm{m}$ wide. The satellite pegmatites to the northwest and northeast are roughly ovoid in plan and do not exceed $30 \mathrm{~m}$ in average diameter. Six concentric zones constitute the three bodies. A thin, discontinuous fine-grained border zone $(\mathrm{Qtz}+\mathrm{Ms})$ is followed by the wall zone (fine- to medium-grained $\mathrm{Kfs}+\mathrm{Ab}+\mathrm{Qtz}+\mathrm{Ms}$ ), outer intermediate zone (medium- to coarse-grained Kfs + Qtz $+\mathrm{Ab}+\mathrm{Ms}$ ), middle intermediate zone (seriate $\mathrm{Ab}+\mathrm{Qtz}$ + Ms with local "cleavelandite", book muscovite and beryl), inner intermediate zone (giant crystals of K-feldspar and masses of milky quartz, pods of $\mathrm{Qtz}+\mathrm{Ab}+$ Ms and sunbursts of Ms), and a core of milky quartz.

Most of the accessory minerals are found in the inner-intermediate and core-margin zones at El Criollo: ferrocolumbite, uraninite, manganoan apatite, hematite, genthelvite, pyrite, chalcopyrite, chalcocite, tetradymite, fluorite, pachnolite and nodules of triplite-zwieselite up to $4 \mathrm{~m}$ across. Hydrothermal and supergene alteration of the primary phosphates generated a rich assemblage of secondary minerals, described in numerous publications (summarized by Demartin et al. 1997).

The rock-forming perthite of the northeastern El Criollo satellite shows a rather modest degree of fractionation. In 14 samples from the blocky intermediate and core-margin zones, $\mathrm{K}_{2} \mathrm{O}$ ranges from 9.99 to 11.54 wt. $\%, \mathrm{Na}_{2} \mathrm{O}$ varies inversely from 3.94 to 2.82 wt. $\%$, with $\mathrm{Rb}_{2} \mathrm{O}$ from 0.08 to 0.12 wt.\%. These data indicate that the primary homogeneous, pre-exsolution alkali feldspar ranged from 35 to 25 mole $\% \mathrm{Ab}_{\mathrm{ss}}$. The values of the $\mathrm{K} / \mathrm{Rb}$ ratio (wt.) vary from 128 to 81 . The $\mathrm{K}$-feldspar component of the perthite is intermediate microcline. Most of the 11 samples examined give triclinicity values between 0.37 and 0.67 ; in all cases, the $131+$ $1 \overline{3} 1$ peaks are accompanied by broad shoulders and intervening "fill-in", indicative of the presence of randomly disordered phases with higher as well as lower triclinicities. Only two samples yielded a single but broad 131 peak indicative of a dominant mnoclinic feldspar. 


\section{The late feldspars}

The only cavity encountered to date in the northeastern satellite yielded a crystal of rust-colored perthitic K-feldspar, flattened parallel to (001). An overgrowth of gemmy nonperthitic K-feldspar is rather thin on prismatic faces but about $10 \mathrm{~mm}$ thick on (010) of the perthitic substrate (Fig. 2A). The overgrowth is deeply corroded, with smooth curved embayments (Fig. 2B). Epitactic crystals of albite, flattened parallel to (010), populate the $\{110\}$ faces of the K-feldspar (Fig. 2C); they are particularly large on the (010) steps in the (110) face (Figs. 2B, C), but are not developed on the main crystal-defining (010) faces. A crystal of smoky quartz is attached to the $(00 \overline{1})$ face of the $\mathrm{K}$-feldspar (Figs. 2B, C).

The K-feldspar phase of the perthitic crystal substrate has an average composition of $\mathrm{Or}_{89.7} \mathrm{Ab}_{7.8} \mathrm{Rbf}_{0.3}$ $\operatorname{LEf}(?)_{1.1}\left(\square \mathrm{Si}_{4} \mathrm{O}_{8}\right)_{1.2}$ (Table 1, Figs. 3A, B). It is optically monoclinic with (-)2V of $\sim 55$ to $60^{\circ}$ and an optic axial plane normal to (010), except for incipient grid twinning in the feldspar immediately adjacent to exsolved albite. X-ray powder-diffraction patterns point to a monoclinic phase, orthoclase, but with $\mathrm{Al}$ consider- ably concentrated at $2 \mathrm{t}_{1}$, indicative of a high degree of (Al,Si) order (Table 2, Fig. 4). The exsolved albite, $\mathrm{Ab}_{98.1} \mathrm{An}_{1.2} \mathrm{Or}_{0.9}$, is close to the composition of the $\mathrm{Ab}$ end member (Table 1, Figs. 3A, B), and the few peaks attributed to albite that could be observed in X-ray powder-diffraction patterns of the perthite correspond to low albite. By optical estimate, exsolved albite amounts to $\sim 12$ vol.\% of the perthitic intergrowth; thus the total of perthitic and residual unexsolved albite averages at $\sim 22$ mole $\% \mathrm{Ab}_{\mathrm{ss}}$ in the homogeneous primary alkali feldspar at the time of crystallization.

The gemmy nonperthitic overgrowth, sharply separated from the perthitic substrate, averages at $\mathrm{Or}_{91.6}$ $\mathrm{Ab}_{6.1} \operatorname{Rbf}_{0.5} \mathrm{Cn}_{0.2} \operatorname{Srf}_{0.1} \operatorname{LEf}(?)_{0.2}\left(\square \mathrm{Si}_{4} \mathrm{O}_{8}\right)_{1.5}$ (Table 1, Figs. 3C, D). This feldspar is optically homogeneous and monoclinic, with $(-) 2 \mathrm{~V}$ of $\sim 55^{\circ}$ and optic axial plane normal to (010). The $\mathrm{X}$-ray powder-diffraction pattern indicates a single monoclinic phase with unitcell dimensions of orthoclase but with $\mathrm{Al}$ strongly ordered at $2 t_{1}$, similar to that of the orthoclase matrix of the perthite cited above (Table 2, Fig. 4).

The epitactic albite shows slightly divergent fanningout growth in the $\{110\}$ crystal terminations of the crystals, with locally developed twinning according to the

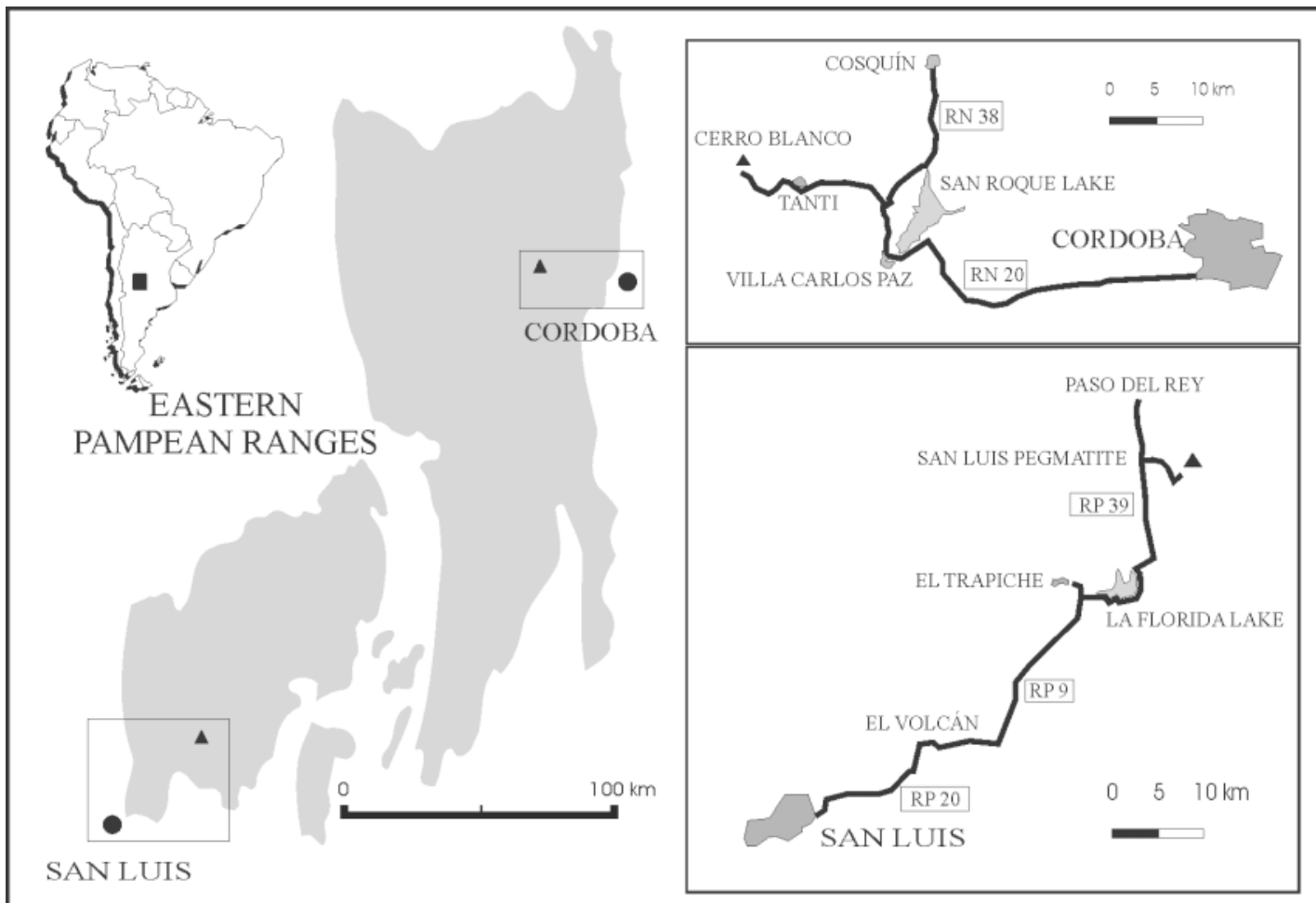

FIG. 1. Location of the Cerro Blanco and San Luis II pegmatites in the eastern Pampean Ranges of Argentina. 

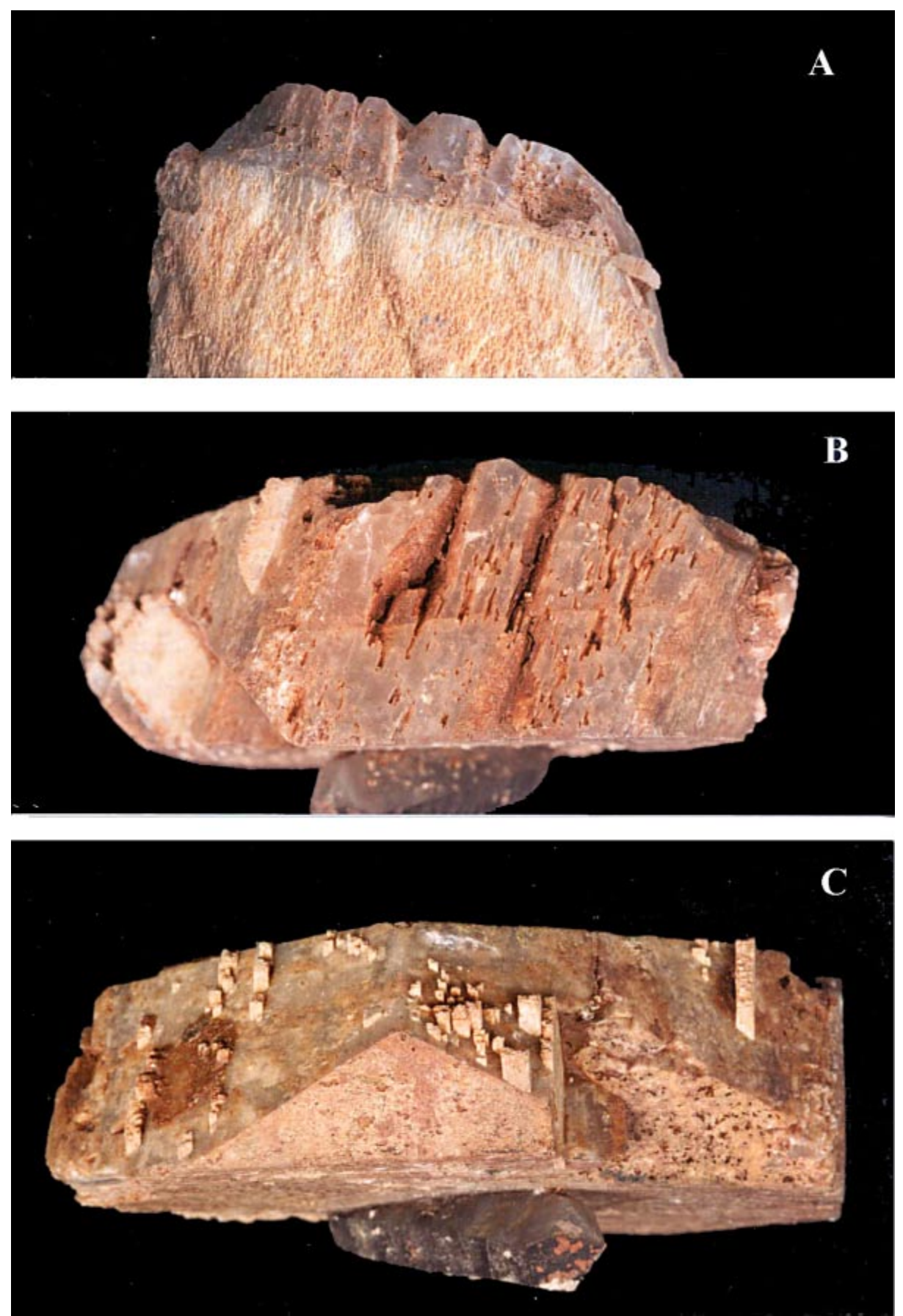

FIG. 2. The feldspar sample from El Criollo pegmatite. A. View perpendicular to (001), showing cleavage surface of main perthitic K-feldspar (rusty to off-white), with overgrowth of nonperthitic corroded orthoclase (pale grey), mainly on subhorizontally oriented (010) and much thinner on (110) sloping down to the right. The actual thickness of the nonperthitic orthoclase on (010) is $10 \mathrm{~mm}$. B. The coarsely corroded overgrowth of orthoclase viewed normal to (010), with tabular epitactic albite (white) on the left side, and a crystal of smoky quartz on ( $00 \overline{1})$. C. Crystals of epitactic albite (white, elongate parallel to $c$ ) on the $\{110\}$ faces of the K-feldspar crystal viewed near-parallel to $a$. 
Albite law. The albite is very close to a pure and ordered end-member $\left(\mathrm{Ab}_{99.5} \mathrm{Or}_{0.07}\right.$ : Tables 1 and 2, Figs. 3C, D).

\section{The San Luis II Granitic Pegmatite}

\section{The pegmatite}

The San Luis mine is located at latitude $32^{\circ} 59^{\prime} 20^{\prime \prime S}$ and longitude $65^{\circ} 59^{\prime} 30^{\prime \prime} \mathrm{W}$ in the Totoral pegmatite field of the Eastern Pampean Ranges of San Luis Province (Fig. 1). The Totoral is the southernmost economic field of the LTC rare-element pegmatite belt of the Pampean Ranges. The metamorphic host-rocks of the field consist of schists containing the assemblage muscovite - biotite - quartz - plagioclase - staurolite - sillimanite

TABLE 1. CHEMICAL COMPOSITION OF CAVITY FELDSPARS FROM THE EL CRIOLLO GRANITIC PEGMATITE

\begin{tabular}{|c|c|c|c|c|c|c|c|c|}
\hline & \multicolumn{4}{|c|}{ Perthite } & \multicolumn{4}{|c|}{ Overgrowths } \\
\hline & \multicolumn{2}{|c|}{ K-feldspar } & \multicolumn{2}{|c|}{ Albite } & \multicolumn{2}{|c|}{ K-feldspar } & \multicolumn{2}{|c|}{ Albite } \\
\hline & $\bar{x}(10)$ & $1 \sigma$ & $\bar{x}(3)$ & 10 & $\bar{x}(6)$ & 10 & $\bar{x}(3)$ & $1 \sigma$ \\
\hline $\mathrm{P}_{2} \mathrm{O}_{5}$ wt. $\%$ & 0.16 & 0.20 & 0.17 & 0.02 & 0.00 & 0.00 & 0.00 & 0.00 \\
\hline $\mathrm{SiO}_{2}$ & 65.17 & 0.49 & 68.60 & 0.37 & 65.20 & 0.37 & 69.09 & 0.07 \\
\hline $\mathrm{Al}_{2} \mathrm{O}_{3}$ & 18.33 & 0.18 & 19.74 & 0.14 & 18.11 & 0.05 & 19.25 & 0.03 \\
\hline $\mathrm{Fe}_{2} \mathrm{O}_{3}$ & 0.01 & 0.01 & 0.00 & 0.00 & 0.02 & 0.02 & 0.01 & 0.01 \\
\hline $\mathrm{Na}_{2} \mathrm{O}$ & 0.88 & 0.10 & 11.65 & 0.08 & 0.68 & 0.02 & 11.78 & 0.03 \\
\hline $\mathrm{K}_{2} \mathrm{O}$ & 15.27 & 0.19 & 0.16 & 0.06 & 15.54 & 0.09 & 0.12 & 0.03 \\
\hline $\mathrm{Rb}_{2} \mathrm{O}$ & 0.11 & 0.04 & 0.01 & 0.01 & 0.15 & 0.02 & 0.05 & 0.06 \\
\hline $\mathrm{Cs}_{2} \mathrm{O}$ & 0.01 & 0.02 & 0.00 & 0.00 & 0.01 & 0.01 & 0.00 & 0.00 \\
\hline $\mathrm{CaO}$ & 0.00 & 0.00 & 0.25 & 0.12 & 0.00 & 0.01 & 0.01 & 0.01 \\
\hline $\mathrm{SrO}$ & 0.01 & 0.02 & 0.02 & 0.04 & 0.04 & 0.03 & 0.00 & 0.00 \\
\hline $\mathrm{BaO}$ & 0.02 & 0.05 & 0.00 & 0.00 & 0.10 & 0.08 & 0.00 & 0.00 \\
\hline $\mathrm{PbO}$ & 0.01 & 0.01 & 0.00 & 0.00 & 0.00 & 0.01 & 0.00 & 0.00 \\
\hline$\Sigma$ & 99.98 & & 100.60 & & 99.85 & & 100.31 & \\
\hline Р apfu & 0.006 & 0.008 & 0.006 & 0.001 & 0.000 & 0.000 & 0.000 & 0.000 \\
\hline $\mathrm{Si}$ & 3.001 & 0.017 & 2.981 & 0.007 & 3.013 & 0.005 & 3.008 & 0.001 \\
\hline $\mathrm{Al}$ & 0.995 & 0.010 & 1.001 & 0.007 & 0.986 & 0.006 & 0.988 & 0.002 \\
\hline $\mathrm{Fe}^{3+}$ & 0.000 & 0.000 & 0.000 & 0.000 & 0.001 & 0.001 & 0.000 & 0.000 \\
\hline $\mathrm{Na}$ & 0.078 & 0.009 & 0.981 & 0.007 & 0.061 & 0.002 & 0.995 & 0.002 \\
\hline $\mathrm{K}$ & 0.897 & 0.011 & 0.009 & 0.003 & 0.916 & 0.005 & 0.007 & 0.001 \\
\hline $\mathrm{Rb}$ & 0.003 & 0.001 & 0.000 & 0.000 & 0.005 & 0.001 & 0.001 & 0.002 \\
\hline Cs & 0.000 & 0.000 & 0.000 & 0.000 & 0.000 & 0.000 & 0.000 & 0.000 \\
\hline $\mathrm{Ca}$ & 0.000 & 0.000 & 0.012 & 0.006 & 0.000 & 0.000 & 0.000 & 0.001 \\
\hline $\mathrm{Sr}$ & 0.000 & 0.000 & 0.001 & 0.001 & 0.001 & 0.001 & 0.000 & 0.000 \\
\hline $\mathrm{Ba}$ & 0.000 & 0.001 & 0.000 & 0.000 & 0.002 & 0.001 & 0.000 & 0.000 \\
\hline $\mathrm{Pb}$ & 0.000 & 0.000 & 0.000 & 0.000 & 0.000 & 0.000 & 0.000 & 0.000 \\
\hline$M^{1+}$ & 0.978 & 0.006 & 0.990 & 0.008 & 0.982 & 0.005 & 1.003 & 0.001 \\
\hline$M^{2+}$ & 0.000 & 0.001 & 0.0132 & 0.007 & 0.003 & 0.001 & 0.000 & 0.001 \\
\hline$\Sigma M$ & 0.978 & 0.006 & 1.0032 & 0.003 & 0.985 & 0.006 & 1.003 & 0.001 \\
\hline$M^{+}$ & 0.978 & 0.007 & 1.0164 & 0.007 & 0.988 & 0.008 & 1.003 & 0.000 \\
\hline $\mathrm{TO}_{2}^{-}$ & 0.989 & 0.004 & 0.995 & 0.007 & 0.986 & 0.006 & 0.988 & 0.002 \\
\hline $\mathrm{Si}+2 \mathrm{P}$ & 3.013 & 0.004 & 2.993 & 0.006 & 3.013 & 0.005 & 3.008 & 0.001 \\
\hline$\Sigma T$ & 4.002 & 0.002 & 3.998 & 0.002 & 3.999 & 0.001 & 3.996 & 0.001 \\
\hline $\operatorname{LEf}(?)^{+}$ & 0.011 & & & & -0.002 & & & \\
\hline$\square T$ & 0.013 & & & & 0.013 & & & \\
\hline$\square M$ & 0.011 & & & & 0.017 & & & \\
\hline
\end{tabular}

See "Experimental" for explanation of $M^{1+}$ and other symbols. The analytical results have been recalculated on the basis of 8 atoms of oxygen per formula unit (apfu).
- chlorite, that were intruded by a suite of late-orogenic $\mathrm{S}$-type granites of Ordovician age ( $\mathrm{Rb}-\mathrm{Sr}$ radiometry).

The San Luis pegmatites I and II are located close to granitic intrusions with the textural and chemical attributes typical of fertile granites parental to rare-element pegmatites. The San Luis pegmatites were studied by Herrera (1963), Angelelli \& Rinaldi (1963) and, most recently, by Oyarzábal \& Galliski (1993).

San Luis I, an albite-spodumene-type pegmatite, is 2 to $12 \mathrm{~m}$ wide and $>500 \mathrm{~m}$ long. It is slightly zoned, with a dominant central zone of columnar K-feldspar and spodumene in a granular matrix of albite, quartz and spodumene ( \pm muscovite, garnet). The columnar K-feldspar and spodumene display parallel orientation across the pegmatite. San Luis I was probably synkinematically intruded and folded during an E-W compressional event.

San Luis II, a complex-type spodumene-subtype pegmatite, is located inside some of the anticlinal crests of the San Luis I body. The pegmatite is devoid of any TABLE 2. UNIT-CELL DIMENSIONS AND RELATED PARAMETERS
OF THE FELDSPARS EXAMINED, EL CRIOLLO AND SAN LUIS II GRANITIC PEGMATITES, ARGENTINA

\begin{tabular}{|c|c|c|c|c|c|}
\hline & \multicolumn{3}{|c|}{ El Criollo } & \multirow{2}{*}{\multicolumn{2}{|c|}{$\begin{array}{l}\text { San Luis II } \\
\text { Microcline }\end{array}$}} \\
\hline & \multicolumn{2}{|c|}{ Orthoclase } & \multirow{2}{*}{$\frac{\text { Albite }}{\text { EC-D }}$} & & \\
\hline & EC-A & $\mathrm{EC}-\mathrm{C}$ & & SL-1 & SL-3 \\
\hline$a(\AA)$ & $8.573(3)$ & $8.573(3)$ & $8.143(3)$ & $8.576(2)$ & $8.571(4)$ \\
\hline$b$ & $12.981(4)$ & $12.977(3)$ & $12.788(3)$ & $12.960(2)$ & $12.961(3)$ \\
\hline$c$ & $7.205(2)$ & $7.206(2)$ & $7.159(3)$ & $7.223(1)$ & $7.224(1)$ \\
\hline$\alpha$ & 90 & 90 & $94.20(3)$ & $90.66(1)$ & $90.39(5)$ \\
\hline$\beta$ & $116.05(2)$ & $116.00(2)$ & $116.64(3)$ & $115.97(1)$ & $116.01(3)$ \\
\hline$\gamma$ & 90 & 90 & $87.83(3)$ & $87.65(1)$ & $87.82(3)$ \\
\hline$\dot{V}\left(\AA^{3}\right)$ & $720.3(3)$ & $720.6(2)$ & $664.6(3)$ & $721.1(2)$ & $720.6(3)$ \\
\hline Strain index & -1.98 & -1.33 & 0.20 & -5.26 & -7.69 \\
\hline $2 t_{1}$ & $\begin{array}{l}0.824 \\
0.820\end{array}$ & $\begin{array}{l}0.839 \\
0.85 I\end{array}$ & - & - & - \\
\hline $\mathrm{t}_{1} \mathrm{o}+\mathrm{t}_{1} \mathrm{~m}$ & - & - & $\begin{array}{l}0.999 \\
0.981\end{array}$ & $\begin{array}{l}1.011 \\
1.01\end{array}$ & $\begin{array}{l}1.016 \\
1.007\end{array}$ \\
\hline $\mathrm{t}_{1} \mathrm{o}-\mathrm{t}_{1} \mathrm{~m}$ & - & - & $\begin{array}{l}0.932 \\
0.939\end{array}$ & $\begin{array}{l}1.007 \\
1.007\end{array}$ & $\begin{array}{l}0.927 \\
0.934\end{array}$ \\
\hline$t_{1} \mathrm{o}$ & - & - & $\begin{array}{l}0.965 \\
0.960\end{array}$ & $\begin{array}{l}1.009 \\
1.006\end{array}$ & $\begin{array}{l}0.972 \\
0.971\end{array}$ \\
\hline$t_{1} m$ & - & - & $\begin{array}{l}0.035 \\
0.040\end{array}$ & $\begin{array}{l}-0.009 \\
-0.006\end{array}$ & $\begin{array}{l}0.028 \\
0.021\end{array}$ \\
\hline $\begin{array}{l}2 \mathrm{t}_{1} \text { from } \Delta(b c) \\
2 \mathrm{t}_{1} \text { from } \Delta\left(b^{*} c^{*}\right)\end{array}$ & $\begin{array}{l}0.841 \\
0.800\end{array}$ & $\begin{array}{l}0.858 \\
0.832\end{array}$ & & & \\
\hline$t_{1} o+t_{1} m$ from $\Delta(b c)$ & & & 0.980 & 1.016 & 1.021 \\
\hline$t_{1} \mathrm{o}+\mathrm{t}_{1} \mathrm{~m}$ from $\Delta\left(b^{*} c^{*}\right)$ & & & 0.961 & 1.011 & 0.996 \\
\hline$t_{1} o+t_{l} m$ from $\Delta(\alpha \gamma)$ & & & 0.937 & 1.008 & 0.934 \\
\hline$t_{1} o+t_{1} m$ from $\Delta\left(\alpha^{*} \gamma^{*}\right)$ & & & 0.936 & 1.008 & 0.933 \\
\hline
\end{tabular}

EC-A: Kfs host of main-crystal perthite; EC-C: single-phase orthoclase overgrowth; EC-D: epitactic albite; SL-1: Kfs host of the main-crystal perthite; SL-3: nonperthitic overgrowth. The strain index was calculated from Kroll \& Ribbe (1987, eq. 25 and 26); $\mathrm{Al}$ in $2 \mathrm{t}_{1}$ for monoclinic and $\left(\mathrm{t}_{1} \mathrm{o}+\mathrm{t}, \mathrm{m}\right)$ for triclinic feldspars calculated from Kroll \& Ribbe (1983, eq. 10a and 10b, respectively), and from Kroll \& Ribbe (1987, eq. 5 and 6 , respectively); $\left(\mathrm{t}_{1} \mathrm{o}-\mathrm{t}_{1} \mathrm{~m}\right)$ calculated from Kroll \& Ribbe (1983, eq. 11), and from Kroll \& Ribbe (1987, eq. 12); data calculated from the classic $\Delta$ values courtesy of A. Blasi. 
preferred orientation of minerals characteristic of San Luis I. The internal structure of San Luis II is more complex, consisting of border, wall, intermediate and core zones. The discontinuous Ms + Qtz border zone grades into the wall zone with large $\mathrm{K}$-feldspar crystals, in part with graphic quartz, in a matrix of $\mathrm{Ms}+\mathrm{Qtz}+\mathrm{Ab}$. Increasing grain-size characterizes the intermediate zone, with large $\mathrm{K}$-feldspar $(\leq 2 \mathrm{~m})$ and spodumene $(\leq 1.5 \mathrm{~m})$ in interstitial quartz. Large crystals of spodumene also occur in the core margin, locally with pods of "cleavelandite" + muscovite hosting grains of manganotantalite. The outer part of the quartz core carries pyrite-bearing nodules of triphylite-lithiophilite, in part altered to secondary phosphates. Opal, "jasper" and subordinate "chalcedony", covered by fine crystals of quartz and calcite, and locally coated by goethite and pyrolusite, fill fractures and vugs in massive quartz of the intermediate zones and the core.

The rock-forming perthitic K-feldspar of the San Luis II pegmatite shows a generally moderate degree of fractionation. Across the pegmatite zones, the $\mathrm{K}$ content increases from 13.02 to $14.47 \mathrm{wt} \% \mathrm{~K}_{2} \mathrm{O}, \mathrm{Rb}$ from 0.18 to 0.38 wt. $\% \mathrm{Rb}_{2} \mathrm{O}$, and $\mathrm{Na}$ drops from 2.35 to 1.60 wt. $\% \mathrm{Na}_{2} \mathrm{O}$. Accordingly, the primary homogeneous alkali feldspar is estimated to have ranged from 21 to 14 mole $\%$ in $\mathrm{Ab}_{\mathrm{ss}}$. The values of the $\mathrm{K}: \mathrm{Rb}$ (wt.) ratio vary from 69 to 35 . The K-feldspar has a consistently high degree of $(\mathrm{Al}, \mathrm{Si})$ order. Triclinicity varies between 0.88 and 1.00 , with $60 \%$ of the 26 values collected greater than 0.93. Optically, cross-hatched twinning is well developed and relatively coarse.

\section{The late feldspars}

Crystals of late K-feldspar were found in a miarolitic cavity in the core-margin quartz. The crystals attain 12 by 6 by $4 \mathrm{~cm}$ in size, but most are much smaller, a few $\mathrm{cm}$ in longest dimension. The crystals are short columnar, elongate parallel to $a$, with a near-square cross-section normal to this axis. Prismatic faces are evident in the terminations. The crystals consist of a volumetrically dominant perthitic core, locally altered to muscovite and clay minerals, and a nonperthitic outer zone (Fig. 5).

The core consists of microcline perthite with optically well-defined cross-hatched twinning of the K-feldspar matrix and short round-ended veinlets of perthitic albite subparallel to $\{100\}$. The K-feldspar matrix shows minor incorporation of light elements (probably $\mathrm{Li}$ or $\mathrm{H}$, or both) and the $\square \mathrm{SiO}_{4}$ component; the average composition corresponds to $\mathrm{Or}_{92.3} \mathrm{Ab}_{4.1} \mathrm{Rbf}_{1.1} \mathrm{Csf}_{0.1}$ $\mathrm{Cn}_{0.1} \operatorname{Srf}_{0.1} \operatorname{LEf}(\text { ? })_{1.5}\left(\square \mathrm{Si}_{4} \mathrm{O}_{8}\right)_{0.8}$ (Table 3, Figs. 6A, B). The albite in the perthite has an almost ideal stoichiometry, $\mathrm{Ab}_{99.1} \mathrm{An}_{0.1} \mathrm{Or}_{0.4} \mathrm{Cn}_{0.1} \mathrm{Srf}_{0.1}$ (Table 3, Figs. 6A, B). By optical estimate, the veinlets constitute $\sim 8$ vol. $\%$ ( 7 wt. \%) of the perthitic intergrowth; a combination with the EMP-established Na content of the host given above indicates $\sim 13$ mole $\% \mathrm{Ab}_{\mathrm{ss}}$ in the primary homogeneous alkali feldspar at the time of crystallization.
Unit-cell dimensions and related parameters of the $\mathrm{K}$-feldspar phase are very close to those of end-member low microcline (Table 2, Fig. 4). The few X-ray powder-diffraction peaks that could be observed among those of the dominant microcline correspond to low albite. The microcline can be expected to be unstrained, as the perthitic albite is coarse and sparse, and the interfaces of the two feldspars probably are incoherent.

The microcline perthite is locally leached and altered to Fe-bearing muscovite. Its average composition, normalized to 12 anions (with all Fe assumed trivalent), gives cation contents close to those of normal muscovite, except for a slight excess of $\mathrm{Si}$ over ${ }^{\mathrm{IV}} \mathrm{Al}(\mathrm{Si} / \mathrm{Al}=$ 3.57). The concentration of lithium was not determined, but in view of the very low F content and lack of octahedral vacancies, any potential Li content should be negligible.

The nonperthitic microcline composing the outer rim of the crystals examined and the related isolated grains averages $\mathrm{Or}_{92.8} \mathrm{Ab}_{4.8} \mathrm{Rbf}_{0.2} \mathrm{Srf}_{0.1} \mathrm{Cn}_{0.1} \operatorname{LEf}(?)_{1.8}$ $\left(\square \mathrm{Si}_{4} \mathrm{O}_{8}\right)_{0.3}$ (Table 3). The substitution of the main alkalis by undetermined light elements is distinctly dominant over the Si-"excess" (Figs. 6C, D). The unit-cell dimensions are very close to those of end-member low microcline and virtually identical, within analytical error, to those of the K-feldspar phase of the perthitic interior (Table 2, Fig. 4).

\section{Discussion}

\section{Stoichiometry and structure of late feldspars}

Whereas the albite encountered in this study, from perthitic exsolution-lamellae to late discrete crystals, shows near-ideal stoichiometry and an ( $\mathrm{Al}, \mathrm{Si})$-ordered structure, the story is substantially different for the Kfeldspar phases. Although at both localities the potassic phase shows similar significant departure from "textbook" (K,Na) $\mathrm{AlSi}_{3} \mathrm{O}_{8}$ stoichiometry, the structural state and textural evolution differ markedly.

Both the perthite-host and single-phase-overgrowth orthoclase from El Criollo display a distinct substitution of "excess" silica, $\square \mathrm{Si}(\mathrm{K}, \mathrm{Na})_{-1} \mathrm{Al}_{-1}$ (Table 1, Fig. 3). The same substitution is present in the San Luis II low microcline, combined with substitution of light elements at the $M$ site, probably Li or an H-bearing species, or both (Table 3, Fig. 6). These deviations from the classic formula of a feldspar are to be expected: both substitutions are widespread in K-feldspar of broadly variable structural state from peraluminous granitic pegmatites, in contrast to their counterparts from plutonic rocks and at least some pegmatites with peralkaline tendencies (e.g., Teerststra 1997, Teertstra et al. 1998a, b, 1999 and Blasi et al. 1984, respectively).

The potassic host of the perthitic alkali feldspar from El Criollo is "monoclinic" at optical and XRD scales, with very limited incipient grid twinning near perthitic albite, and the single-phase overgrowth is strictly mono- 

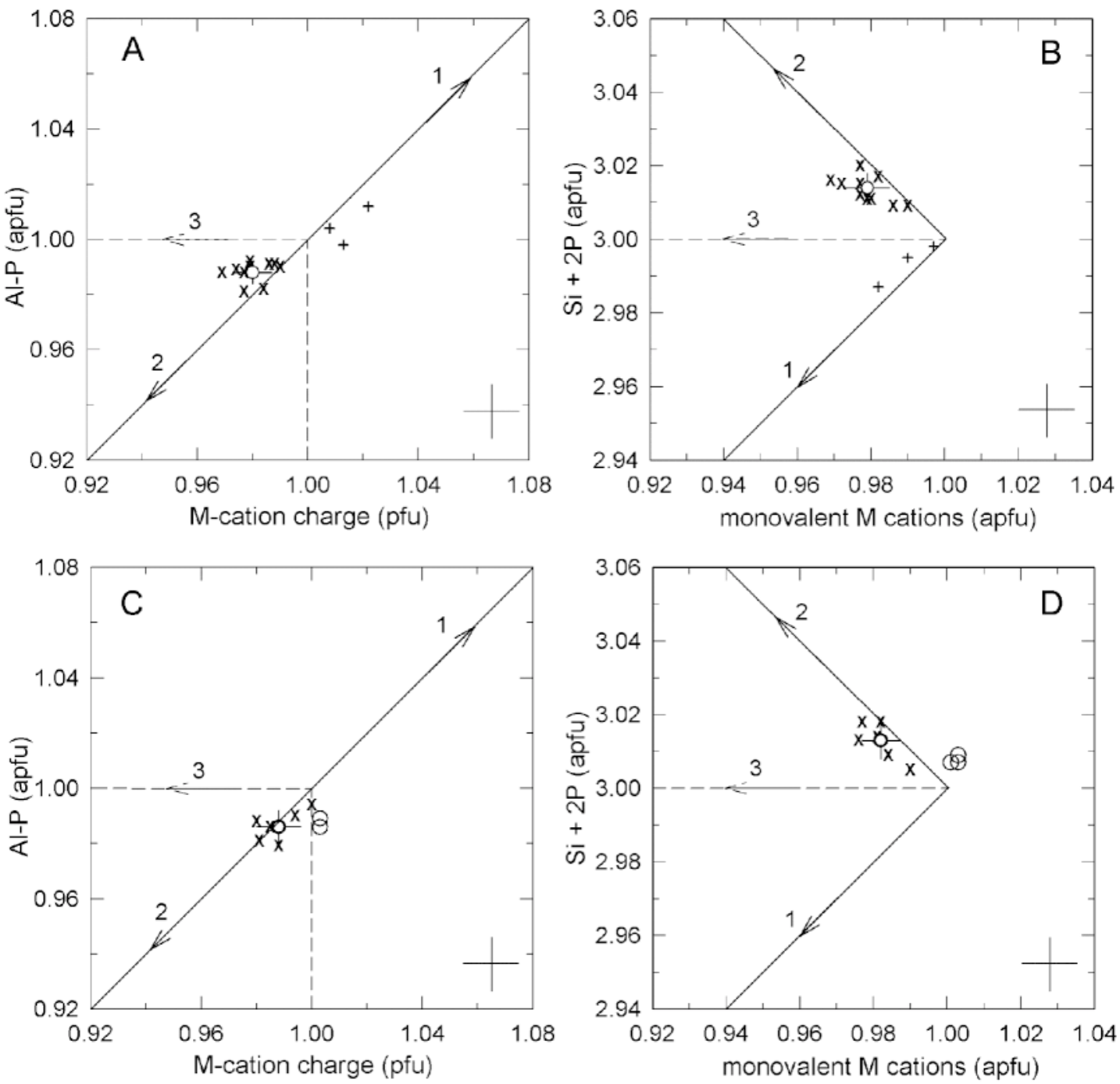

FIG. 3. The El Criollo feldspars. Cation variations in the K-feldspar matrix of perthite (x) and perthitic albite (+) (average of the $\mathrm{K}$-feldspar matrix marked by open circle with $1 \sigma$ standard-deviation bars). $\mathrm{A}$. ( $\mathrm{Al}-\mathrm{P})$ versus $M$-cation charge, with a $1: 1$ trend line. $\mathrm{B} .(\mathrm{Si}+2 \mathrm{P})$ versus sum of monovalent cations. Crosses indicate the precision $(4 \sigma)$ of measurement for the Eifel sanidine standard. Vectors indicate (1) plagioclase-type substitution $\mathrm{M}^{2+} \mathrm{Al}\left(\mathrm{M}^{1+} \mathrm{Si}\right)_{-1}$, (2) the $\square \mathrm{SiO}_{4}$ substitution, and (3) apparent $M$-cation deficiency. $\mathrm{C}$ and $\mathrm{D}$ show the same parameters for the nonperthitic orthoclase overgrowth (x) and epitactic albite (o).

clinic. However, unit-cell dimensions and structural indicators show that these K-feldspars are highly $(\mathrm{Al}, \mathrm{Si})$ ordered (Table 2, Fig. 4). They are undoubtedly very close to the Himalaya "theoretical orthoclase" (Prince et al. 1973), which was interpreted as a strongly coherent domain-twinned microcline with an average monoclinic structure [Smith (1974), Horsky \& Martin (1977), Smith \& Brown (1988); cf. Blasi \& De Pol Blasi (2000) for a discussion of the Himalaya and Spencer $\mathrm{C}$ speci- mens]. The unit-cell dimensions indicate that the two El Criollo orthoclase phases are distinctly less ordered [Al in $2 \mathrm{t}_{1}=0.82$ and 0.84 , in terms of Kroll \& Ribbe (1983)] than the Himalaya counterpart [ $\mathrm{Al}$ in $2 \mathrm{t}_{1}=0.92$; Horsky \& Martin (1977), identical with the $\Delta(b c)$ value of Blasi \& De Pol Blasi (2000)]. In the San Luis II sample, the K-feldspar in both the perthitic core and single-phase overgrowth corresponds to coarse, tartantwinned, near-extreme low microcline (Table 2, Fig. 4). 


\section{Crystallization of late feldspars and subsolidus conditions at El Criollo}

The perthitic K-feldspar core of the main crystal from the El Criollo cavity contained $\sim 22$ mole $\% \mathrm{Ab}_{\mathrm{ss}}$ at the time of crystallization as a single-phase feldspar, distinctly less than even the most Na-poor rock-forming K-feldspar in this pegmatite ( 26 mole $\left.\% \mathrm{Ab}_{\mathrm{ss}}\right)$. The nonperthitic orthoclase overgrowth shows a further decrease in $\mathrm{Na}$, down to 6 mole \% $\mathrm{Ab}_{\mathrm{ss}}$, but a slight increase in $\mathrm{Rb}$. These compositional relations indicate that the currently perthitic cavity-lining crystals did not form from a melt alone as the $\mathrm{K}$-feldspar + quartz of the zone hosting the cavity, but probably from residual melt in the presence of a supercritical aqueous fluid phase. The single-phase, Na-poor orthoclase overgrowth and subsequent epitactic albite show even more significant compositional differences from the perthitic feldspar core; these two feldspars evidently are products of a relatively low-temperature crystallization from the aqueous fluid alone.

The two-feldspar geothermometer cannot be applied to the crystallization of the single-phase precursor of the perthitic core or the single-phase orthoclase overgrowth, as neither of them coexists with a plagioclase (the epitactic albite distinctly postdates the orthoclase over-

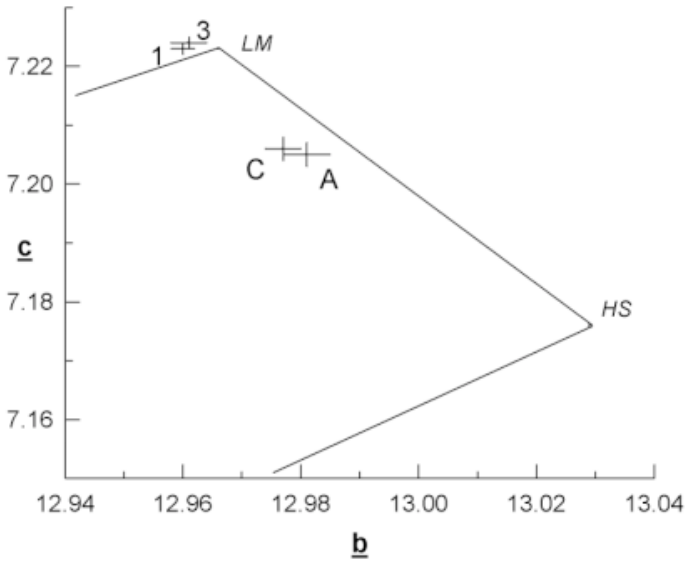

FIG. 4. The $b-c$ diagram for K-Na feldspars, with plots of the potassic phases of the El Criollo sample (A: matrix of perthitic K-feldspar, C: nonperthitic orthoclase overgrowth) and of the San Luis II sample (1: matrix of perthitic microcline, 3: nonperthitic microcline). Crosses indicate $1 \sigma$ standard deviations of unit-cell refinements. End-member HS and LM data from Smith \& Brown (1988).

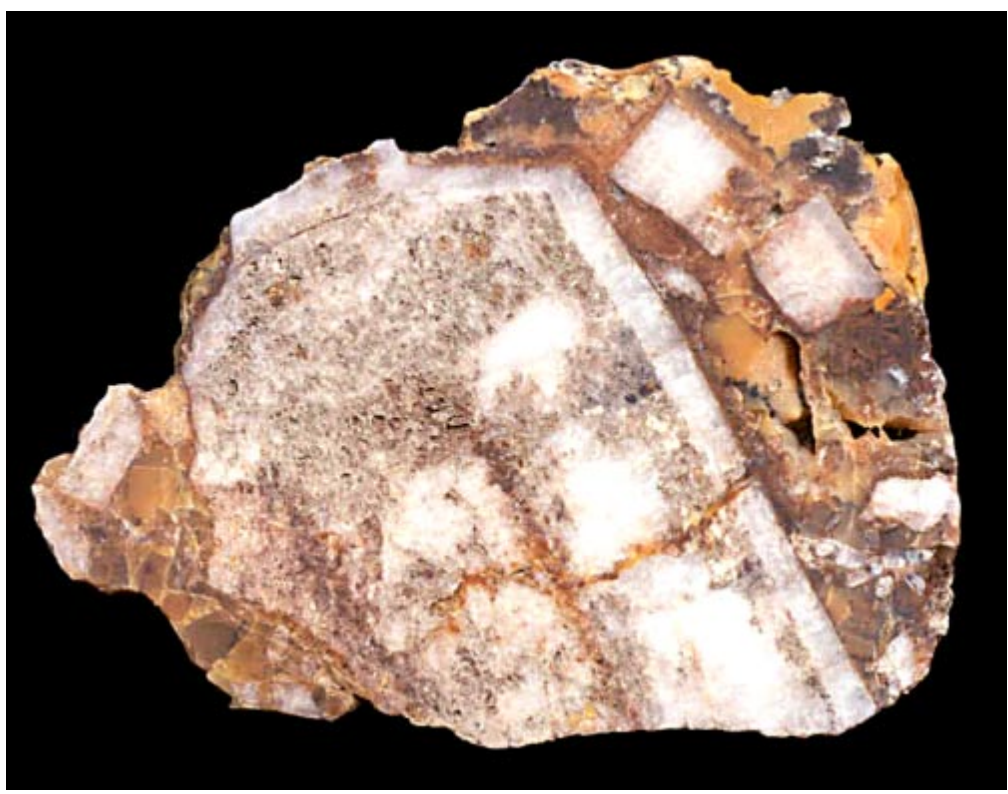

FIG. 5. The feldspar sample from the San Luis II pegmatite, cut in the [010] zone at an oblique angle to $c$; the perthitic microcline (white, mottled, medium grey where altered) in central parts, overgrown by nonperthitic microcline (pale grey to off-white). Rustycolored "chalcedony" and opal fill interstices between the main crystal and smaller ones (top right). The sample is $10 \mathrm{~cm}$ wide. 
growth). The only feasible estimate of temperature is the termination of exsolution in the perthitic core of the main crystal, $380^{\circ} \mathrm{C}$ at a geologically realistic pressure of $\sim 2$ kbar $\mathrm{P}\left(\mathrm{H}_{2} \mathrm{O}\right)$ according to Stormer's (1975) twofeldspar geothermometer. The 8 mole $\% \mathrm{Ab}_{\mathrm{ss}}$ residual in the $\mathrm{K}$-feldspar matrix of the perthite is slightly higher than the 6 mole $\% \mathrm{Ab}_{\mathrm{ss}}$ in the single-phase orthoclase overgrowth: this explains the lack of any exsolution in the latter. The single-phase orthoclase overgrowth could thus have crystallized at or below $380^{\circ} \mathrm{C}$ at $\sim 2 \mathrm{kbar}$.

The rock-forming blocky, perthitic K-feldspar of the parent pegmatite shows a coarsening of the triclinic domains sufficient to generate optically visible gridtwinning and an X-ray powder pattern of intermediate microcline. The perthitic core of the cavity-grown crystal shows only traces of incipient grid twinning in the

TABLE 3. CHEMICAL COMPOSITION OF CAVITY FELDSPARS FROM THE SAN LUIS II GRANITIC PEGMATITE

\begin{tabular}{|c|c|c|c|c|c|c|}
\hline & \multicolumn{4}{|c|}{ Perthite } & \multirow{2}{*}{\multicolumn{2}{|c|}{$\begin{array}{l}\text { K-feldspar } \\
\text { overgrowth and } \\
\text { discrete } \\
\text { grains }\end{array}$}} \\
\hline & \multicolumn{2}{|c|}{$\mathrm{K}$-feldspar } & \multicolumn{2}{|c|}{ Albite } & & \\
\hline & $\bar{x}(12)$ & $1 \sigma$ & $\bar{x}(5)$ & $1 \sigma$ & $\bar{x}(21)$ & $1 \sigma$ \\
\hline $\mathrm{P}_{2} \mathrm{O}_{5}$ wt. $\%$ & 0.08 & 0.26 & 0.07 & 0.06 & 0.03 & 0.00 \\
\hline $\mathrm{SiO}_{2}$ & 64.94 & 0.52 & 69.04 & 0.58 & 65.21 & 0.37 \\
\hline $\mathrm{Al}_{2} \stackrel{\mathrm{O}}{3}_{3}$ & 18.31 & 0.13 & 19.52 & 0.23 & 18.45 & 0.05 \\
\hline $\mathrm{Fe}_{2} \mathrm{O}_{3}$ & 0.02 & 0.02 & 0.01 & 0.01 & 0.01 & 0.02 \\
\hline $\mathrm{Na}_{2} \mathrm{O}$ & 0.45 & 0.16 & 11.78 & 0.14 & 0.54 & 0.02 \\
\hline $\mathrm{K}_{2} \mathrm{O}$ & 15.65 & 0.20 & 0.08 & 0.06 & 15.79 & 0.09 \\
\hline $\mathrm{Rb}_{2} \mathrm{O}$ & 0.36 & 0.23 & 0.01 & 0.02 & 0.08 & 0.02 \\
\hline $\mathrm{Cs}_{2} \mathrm{O}$ & 0.03 & 0.03 & 0.00 & 0.00 & 0.01 & 0.01 \\
\hline $\mathrm{CaO}$ & 0.00 & 0.00 & 0.03 & 0.02 & 0.00 & 0.00 \\
\hline $\mathrm{SrO}$ & 0.03 & 0.03 & 0.03 & 0.02 & 0.04 & 0.03 \\
\hline $\mathrm{BaO}$ & 0.04 & 0.08 & 0.06 & 0.02 & 0.04 & 0.08 \\
\hline $\mathrm{PbO}$ & 0.03 & 0.02 & 0.01 & 0.02 & 0.02 & 0.01 \\
\hline$\Sigma$ & 99.94 & & 100.64 & & 100.22 & \\
\hline Р apfu & 0.003 & 0.002 & 0.003 & 0.002 & 0.001 & 0.000 \\
\hline $\mathrm{Si}$ & 3.003 & 0.009 & 2.997 & 0.004 & 3.002 & 0.005 \\
\hline Al & 0.998 & 0.008 & 0.999 & 0.004 & 1.001 & 0.006 \\
\hline $\mathrm{Fe}^{3+}$ & 0.001 & 0.001 & 0.000 & 0.001 & 0.000 & 0.001 \\
\hline $\mathrm{Na}$ & 0.041 & 0.014 & 0.991 & 0.005 & 0.048 & 0.002 \\
\hline K & 0.923 & 0.011 & 0.004 & 0.003 & 0.928 & 0.005 \\
\hline $\mathrm{Rb}$ & 0.011 & 0.007 & 0.000 & 0.001 & 0.002 & 0.001 \\
\hline $\mathrm{Cs}$ & 0.001 & 0.001 & 0.000 & 0.000 & 0.000 & 0.000 \\
\hline $\mathrm{Ca}$ & 0.000 & 0.000 & 0.001 & 0.001 & 0.000 & 0.000 \\
\hline $\mathrm{Sr}$ & 0.001 & 0.001 & 0.001 & 0.000 & 0.001 & 0.001 \\
\hline $\mathrm{Ba}$ & 0.001 & 0.001 & 0.001 & 0.000 & 0.001 & 0.001 \\
\hline $\mathrm{Pb}$ & 0.000 & 0.000 & 0.000 & 0.000 & 0.000 & 0.000 \\
\hline$M^{1+}$ & 0.976 & 0.008 & 0.995 & 0.007 & 0.978 & 0.007 \\
\hline$M^{2+}$ & 0.002 & 0.002 & 0.003 & 0.001 & 0.002 & 0.001 \\
\hline$\Sigma M$ & 0.978 & 0.008 & 0.998 & 0.007 & 0.980 & 0.008 \\
\hline$M^{+}$ & 0.980 & 0.008 & 1.001 & 0.006 & 0.982 & 0.007 \\
\hline $\mathrm{TO}_{2}^{-}$ & 0.995 & 0.006 & 0.996 & 0.005 & 1.000 & 0.006 \\
\hline $\mathrm{Si}+2 \mathrm{P}$ & 3.009 & 0.006 & 3.002 & 0.005 & 3.004 & 0.005 \\
\hline$\Sigma T$ & 4.003 & 0.002 & 3.998 & 0.001 & 4.004 & 0.002 \\
\hline LEf(?) & 0.015 & & & & 0.018 & \\
\hline$\square T$ & 0.009 & & & & 0.004 & \\
\hline$\square M$ & 0.007 & & & & 0.002 & \\
\hline
\end{tabular}

See "Experimental" for explanation of $M^{1+}$ and other symbols. The raw data have been recalculated on the basis of 8 atoms of oxygen per formula unit (apfu).
K-feldspar host adjacent to exsolved albite, and its bulk contains a monoclinic K-feldspar with high segregation of $\mathrm{Al}$ in $2 \mathrm{t}_{1}$. The overgrowth of optically strictly monoclinic single-phase orthoclase also exhibits an XRD powder pattern of a monoclinic $\mathrm{K}$-feldspar, with a slightly higher concentration of $\mathrm{Al}$ in $2 \mathrm{t}_{1}$. These features suggest that the cavity-lining perthite crystal was subject to post-crystallization energy levels somewhat lower, and possibly of shorter duration, than the rockforming perthite of the surrounding massive zone of the pegmatite, and the single-phase orthoclase overgrowth was even less affected. Relatively high (Al,Si) order was attained by all three feldspar types, but the coarsening of the sub-XRD-twinned microcline domains was severely reduced, or prevented, in the generations of cavity-grown feldspar. The domain-twinned Himalaya and El Criollo nonperthitic K-feldspar probably are structurally stranded, or locked (Horsky \& Martin 1977), and very resistant to changes in texture and size of the twinned domains. The Himalaya-type orthoclase substantially differs from the rather widespread, metastably persistent tweed orthoclase, which is a phase transitional from monoclinic symmetry to triclinic coarse-twinned tartan patterns. Tweed orthoclase proper is characterized by a maximum value of $\Delta(b c)(=\mathrm{Al}$ in $\left.2 \mathrm{t}_{1}\right)=0.72$ [Brown \& Parsons (1989); see Blasi \& De Pol Blasi (2000) for a review of other data that range from 0.68 to 0.80 ], distinctly lower than the Himalaya and El Criollo specimens [0.92 and 0.84, respectively; all numerical values here conform to Kroll \& Ribbe (1983)].

The sum of the data and interpretations above indicates that the growth of epitactic albite, corrosion of the single-phase orthoclase overgrowth and loss of the parent fluid from the El Criollo probably were relatively rapid events. The conditions were sufficient to promote advanced domain-scale ( $\mathrm{Al}, \mathrm{Si}$ )-ordering, but not the development of a coarse pattern of non-coherent twin lamellae of low microcline (or any subsequent coarsening of the domain-scale texture). However, the conditions permitted complete ( $\mathrm{Al}, \mathrm{Si})$-ordering in epitactic albite [see Martin (1974) for experimental proof of disordered crystallization but extremely fast post-solidification ordering in albite]. Lack of alteration of the cavity-lining feldspars and of any late minerals on their surfaces also indicates that any activity of post-feldspar fluid and vapor was quite limited.

\section{Crystallization, ordering and alteration} of the cavity-lining feldspars at San Luis II

The course of primary crystallization of the cavitylining feldspar phases in the San Luis II pegmatite was closely analogous to that at El Criollo. The perthitic core of the K-feldspar contained $\sim 13$ mole $\% \mathrm{Ab}_{\mathrm{ss}}$ at the time of crystallization as a single-phase feldspar, which is distinctly less than the average rock-forming K-feldspar in the core-margin zone $\left(\sim 16\right.$ mole $\left.\% \mathrm{Ab}_{\mathrm{ss}}\right)$. The 

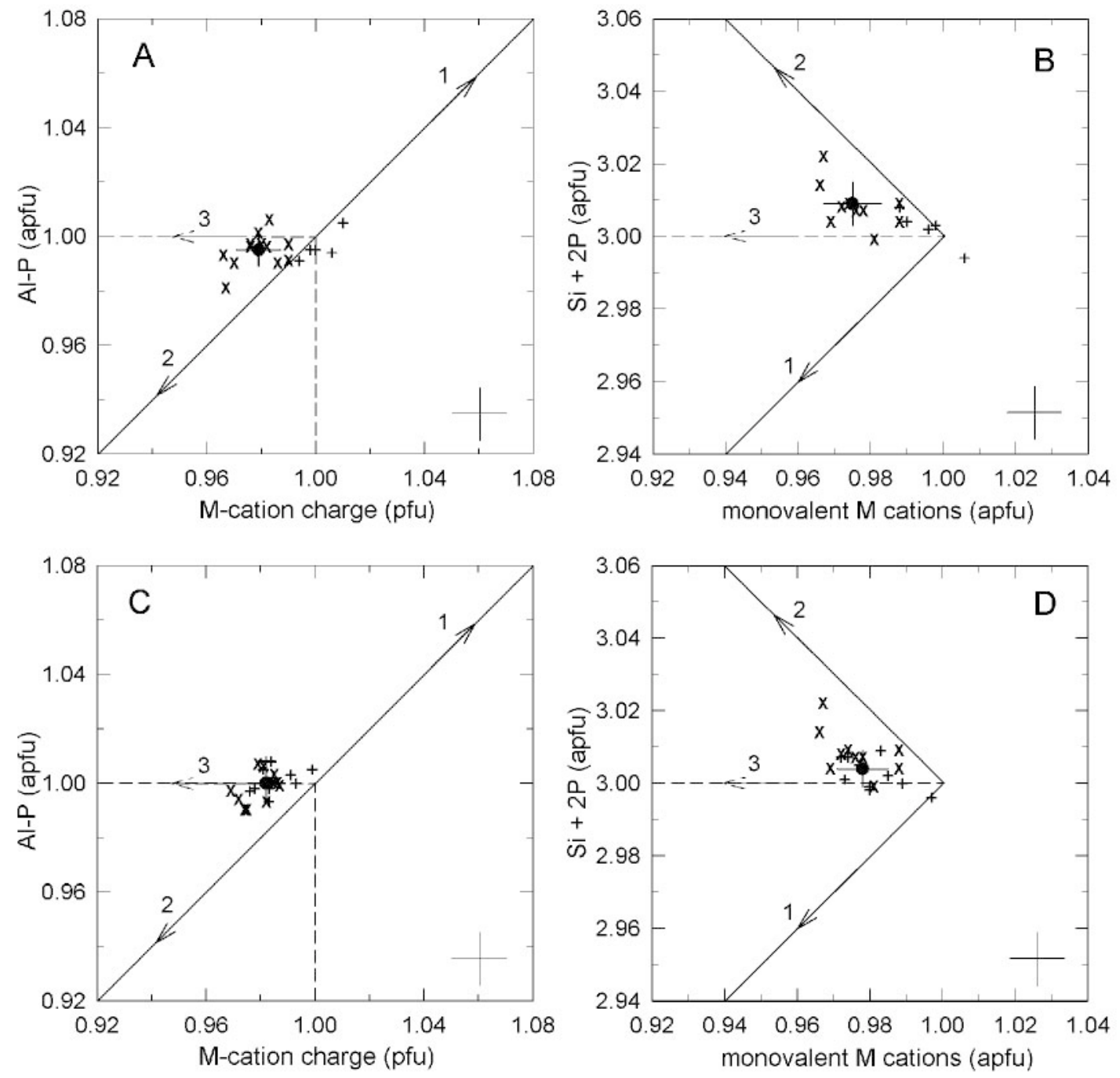

FIG. 6. The San Luis II feldspars. Cation variations in the K-feldspar phase (x) and the perthitic albite (+) of the perthitic microcline core; average of the K-feldspar matrix is marked by open circles with $1 \sigma$ standard-deviation bars. A. (Al - P) versus $M$-cation charge, with a $1: 1$ trend line. $\mathrm{B}$. $(\mathrm{Si}+2 \mathrm{P})$ versus sum of monovalent cations; $\mathrm{C}$ and $\mathrm{D}$ show the same parameters for the nonperthitic microcline overgrowth $(\mathrm{x})$ and isolated late microcline $(+)$. Trend lines and other symbols as in Figure 3.

nonperthitic overgrowth shows a further decrease in $\mathrm{Na}$, down to 5 mole $\% \mathrm{Ab}_{\mathrm{ss}}$; the $\mathrm{Rb}$ content is about the same as in the perthitic core. Crystallization of the homogeneous precursor of the perthitic core from a medium other than a homogeneous silicate melt is again indicated by the lower Na content; precipitation from, or at least in the presence of, an aqueous fluid is very probable, as at El Criollo. The Na-poor nonperthitic overgrowth seems to be a product of precipitation from an aqueous fluid phase alone. Using Stormer's (1975) diagram for $2 \mathrm{kbar} \mathrm{P}\left(\mathrm{H}_{2} \mathrm{O}\right)$, the distribution of $\mathrm{Ab}$ between the K-feldspar matrix and exsolved albite in the perthitic core suggests a closure temperature of exsolution of $\sim 350^{\circ} \mathrm{C}$. The 4 mole $\% \mathrm{Ab}_{\mathrm{ss}}$ residual in the K-feldspar matrix of the perthite is about the same as the 5 mole \% $A b_{s s}$ in the nonperthitic overgrowth. This accounts for the lack of exsolution in the latter, and suggests that it crystallized at or below $350^{\circ} \mathrm{C}$ at $\sim 2 \mathrm{kbar}$. 
The subsolidus effects in the San Luis II feldspars are, however, very different from those observed at El Criollo. The perthitic core of the cavity-grown crystal developed coarse optically visible grid-twinning and virtually complete $(\mathrm{Al}, \mathrm{Si})$-order, in accord with very advanced conversion to microcline of all rock-forming K-feldspar in the pegmatite. Despite the low temperature of crystallization of the nonperthitic overgrowth, this phase also was converted to grid-twinned, near-endmember low microcline. In contrast to the El Criollo cavity, which lacks any late minerals covering or forming at the expense of the feldspars, the San Luis II perthitic core is in part leached and altered to muscovite. Interstices between the nonperthitic overgrowth zones are coated by, or completely filled with, a lowtemperature assemblage of fine-grained quartz, "chalcedony", opal, goethite and pyrolusite. This evidence points to extensive hydrothermal activity promoting $(\mathrm{Al}, \mathrm{Si})$-ordering in the nonperthitic overgrowth to an optically and XRD-defined low microcline with the classic coarse set of incoherent exsolution-lamellae.

It is tempting to correlate the ordering in the San Luis II nonperthitic overgrowth with the general conditions prevalent at the subsolidus stage of the whole pegmatite that led to the overall $(\mathrm{Al}, \mathrm{Si})$-ordering trend in rockforming K-feldspar. However, this conversion, accompanied by exsolution of albite, undoubtedly proceeded at temperatures higher than crystallization of the nonperthitic overgrowths, as discussed above. Also, numerous examples are documented of late low-temperature sanidine preserved in pegmatite cavities with rock-forming and cavity-lining K-feldspar converted to perthitic intermediate to low microcline (e.g.. Černý 1972, Foord \& Martin 1979, Blasi et al. 1984, Cerný \& Chapman 1984, Martin \& Falster 1986, Ferguson et al. 1991, Teertstra 1997, Teertstra et al. 1998a, b). The cavity-grown feldspar grains from the El Criollo pegmatite also document their subsolidus structural evolution as separate from that of the rock-forming phases. Thus the subsolidus fate of late single-phase K-feldspar is not necessarily (and not usually) identical with that of either its cavity-lining perthite substrate or rock-forming perthite at large. The crystallization of the late generation of feldspar may occur after prior rock-forming feldspars have undergone structural transformation and exsolution. The late cavity-lining feldspars can be affected by local low-temperature processes separate from, and following those controlling the subsolidus history of the rock-forming phases at large.

\section{Conclusions}

The present study contributes to our understanding of the general tendency of granitic pegmatites to generate late, low-temperature, cavity- or fissure-grown $\mathrm{K}$ feldspar phases. They may be preserved in their original state as metastable disordered phases or substantially modified, depending on the degree of subsequent fluiddominated activity. Conditions that best preserve the original phase composition, structural state and chemical composition are documented by assemblages that lack evidence of post-feldspar alteration and deposition of hydrothermal minerals. If exposed to such a superimposed action, $\mathrm{K}$-feldspar exhibits ( $\mathrm{Al}, \mathrm{Si})$-ordering, exsolution (where sufficiently Na-rich) and alteration. However, the ordering may follow different pathways: development of the common coarse grid-twinned pattern of incoherent twins, or the apparently rare, coherent, sub-X-ray twinning, locked at domain scale.

The characteristics of the El Criollo single-phase orthoclase overgrowth show that the Himalaya domaintwinned, highly ordered but pseudomonoclinic-behaving "stranded" orthoclase is not as unique as previously thought. Continued examination of paragenetically similar feldspar phases may reveal further occurrences that may shed better light on the specific conditions generating this structural oddity.

\section{ACKNOWLEDGEMENTS}

This work was supported by the NSERC Major Installation and Research Grants to PC and Major Equipment and Infrastructure Grants to Frank C. Hawthorne (University of Manitoba). The field work of MAG and JCO and the graduate thesis of JCO were financed by the PID 319/98 grant from CONICET and a grant from Fundacion Antorchas, and the 349001 grant from UNSL, respectively. The unique sample from El Criollo pegmatite was graciously loaned to the authors by the owner of the pegmatite mine, Sra. Catalina Benimelis of Villa Carlos Paz, Córdoba. The assistance of Neil Ball and Sergio Mejia (University of Manitoba) in the laboratory work is gratefully acknowledged. The critical reviews of Drs. Achille Blasi and Thomas Plymate and the editorial clean-up by Robert F. Martin considerably improved the manuscript.

\section{REFERENCES}

Angelelli, V. \& Rinaldi, C.A. (1963): Yacimientos de minerales de litio de las provincias de San Luis y Córdoba. Com. Nac. Energ. Atom. Buenos Aires, Inf. 91.

Appleman, D.E. \& Evans, H.T., JR. (1973): Job 9214: indexing and least-squares refinement of powder diffraction data. U.S. Geol. Surv., Comput. Contrib. 20 (NTIS Doc. PB216188).

Blasi, A \& De Pol Blasi, C. (1994): Aspects of alkali feldspar characterization: prospects and relevance to problems outstanding. In Feldspars and Their Reactions (I. Parsons, ed.). NATO Adv. Study Inst. Ser. C 421, 51-101.

$\&$ (2000): Crystal structures of alkali feldspars from granitic pegmatites: a review. Mem. Soc. Ital. Museo Civ. Storia Nat. Milano 30, 73-109. 
Brajkovic, A. \& De Pol Blasi, C. (1984): Dryheating conversion of low microcline to high sanidine via a one-step disordering process. Bull. Minéral. 107, 423-435.

BorG, I.Y. \& SMITH, D.K. (1969): Calculated X-ray powder patterns for silicate minerals. Geol. Soc. Am., Mem. 122.

BRown, W.L. \& PARsons, I. (1989): Alkali feldspars: ordering rates, phase transformations and behaviour diagrams for igneous rocks. Mineral. Mag. 53, 25-42.

ČERNÝ, P. (1972): The Tanco pegmatite at Bernic Lake, Manitoba. VIII. Secondary minerals from the spodumene-rich zones. Can. Mineral. 11,714-726.

(1994): Evolution of feldspars in granitic pegmatites. In Feldspars and Their Reactions (I. Parsons, ed.). Kluwer Academic Publishers, Amsterdam, The Netherlands (501540).

\& Chapman, R. (1984): Paragenesis, chemistry and structural state of adularia from granitic pegmatites. Bull. Minéral. 107, 369-384.

$\&$

(1986): Adularia from hydrothermal vein deposits: extremes in structural state. Can. Mineral. 24, 717-728.

Demartin, F., Gay, H.D., Gramaccioli, C.M. \& Pilati, T. (1997): Benyacarite, a new titanium-bearing phosphate mineral species fom Cerro Blanco, Argentina. Can. Mineral. 35, 707-712.

Ferguson, R.B, BALl, N.A. \& ČERnÝ, P. (1991): Structure refinement of an adularian end-member high sanidine from the Buck Claim pegmatite, Bernic Lake, Manitoba. Can. Mineral. 29, 543-552.

Foord, E.E. \& MARTIN, R.F. (1979): Amazonite from the Pikes Peak batholith. Mineral. Rec. 10, 373-384.

Gallagher, M.J. \& Jutorán, A. (1971): Geología de las pegmatitas "El Criollo" y "El Gaucho", departamento de Punilla, provincia de Córdoba. Prim. Simp. Nac. Geol. Econ. 1, 213-226.

Herrera, A. (1963): Las pegmatitas de la Provincia de San Luis, estructura, mineralogía y génesis. Revista Asoc. Geol. Argentina 18, 43-71.

HoRsky, S.J. \& MARTIN, R.F. (1977): The anomalous ion-exchange behavior of "ordered" orthoclase. Am. Mineral. 62, 1191-1199.

KRolL, H. \& RibBE, P.H. (1983): Lattice parameters, composition and Al,Si order in alkali feldspars. In Feldspar Mineralogy (P.H. Ribbe, ed.; second edition). Rev. Mineral. 2, 57-99.

$\&$

(1987): Determining (Al,Si) distribution and strain in alkali feldspars using lattice parameters and diffraction peak positions: a review. Am. Mineral. 72, 491-506.

LinARES, E. \& LATORRE, C.O. (1969): Edades potasio-argon y plomo-alfa de rocas graníticas de las Provincias de Córdoba y San Luis. Cuartas Jorn. Geol. Arg., Actas 2, 195-204.

MARTIN, R.F. (1974): Controls of ordering and subsolidus phase relations in the alkali feldspars. In The Feldspars, Proc. NATO Advanced Studies Institute (W.S. MacKenzie \& J. Zussman, eds.). Manchester University Press, Manchester, U.K. (313-336).

\& FALSTER, A.U. (1986): Proterozoic sanidine and microcline in pegmatite, Wausau Complex, Wisconsin. Can. Mineral. 24, 709-716.

Morteani, G., Preinfalk, C., Spiegel, W. \& Bonalumi, A. (1995): The Achala granitic complex and the pegmatites of the Sierras Pampeanas (northwest Argentina): a study of differentiation. Econ. Geol. 90, 636-647.

Oyarzábal, J.C. \& Galliski, M.A. (1993): Geología del yacimiento San Luis: un caso de yuxtaposición de tipologías diferentes en pegmatitas de clase elementos raros. Actas XII Congr. Geol. Argentino y Congr. Explor. Hidrocarb. 5, 167-174.

Pouchou, J.L. \& PichoiR, F. (1984): A new model for quantitative analysis. I. Application to the analysis of homogeneous samples. Rech. Aérosp. 3, 13-38.

$\&$ (1985): "PAP" $(\phi-\rho-Z)$ procedure for improved quantitative microanalysis. In Microbeam Analysis (J.T. Armstrong, ed.). San Francisco Press, San Francisco, California (104-106).

Prince, E., Donnay, G. \& Martin, R.F. (1973): Neutron diffraction refinement of an ordered orthoclase structure. Am. Mineral. 58, 500-507.

Sмith, J.V. (1974): Feldspar Minerals. 2. Chemical and Textural Properties. Springer-Verlag, New York, N.Y.

\& Brown, W.L. (1988): Feldspar Minerals. 1. Crystal Structures, Physical, Chemical and Microtextural Properties. Springer-Verlag, Berlin, Germany.

STORMER, J.C., JR. (1975): A practical two-feldspar geothermometer. Am. Mineral. 60, 667-674.

TEERTSTRA, D.K. (1997): Reactions of (K,Rb)-Feldspars from Rare-Element Granitic Pegmatites. Ph.D. thesis, Univ. of Manitoba, Winnipeg, Manitoba.

ČERnÝ, P., Hawthorne, F.C. (1998b): Rubidium feldspars in granitic pegmatites. Can. Mineral. 36, 483-496.

$\&$

(1999): Geochemistry and petrology of late $\mathrm{K}$ - and $\mathrm{Rb}$-feldspars in the Rubellite pegmatite, Lilypad Lakes, NW Ontario. Mineral. Petrol. $\mathbf{6 5}, 237-247$. 
PIER, J., WANG, LU-Min \& EwING, R.C. (1998a): Rubicline, a new feldspar from San Piero in Campo, Elba, Italy. Am. Mineral. 83, 1335-1339.

Wright, T.L. \& Stewart, D.B. (1968): X-ray and optical study of alkali feldspar. I. Determination of composition and structural state from refined unit cell parameters and 2V. Am. Mineral. 53, 38-87.

Received January 25, 2003, revised manuscript accepted August 6, 2003. 